\title{
Comparison of colon-cleansing methods in preparation for colonoscopy - Comparative efficacy of solutions of mannitol, sodium picosulfate and monobasic and dibasic sodium phosphates ${ }^{1}$
}

\author{
Estudo comparativo entre as soluções de manitol, picossulfato de sódio e fosfato \\ monobásico e dibásico de sódio no preparo de cólon para colonoscopia
}

\author{
Paulo Miki Jr, Carlos Renato dos Reis Lemos" ${ }^{\mathrm{II}}$, Pedro Popoutchi"II, Ricardo Luiz dos Santos Garcia ${ }^{\mathrm{IV}}$, José Joaquim \\ Ribeiro da Rochav ${ }^{\mathrm{V}}$ Omar Feres ${ }^{\mathrm{VI}}$
}

I Fellow PhD degree, Division of Coloproctology, Department of Surgery and Anatomy, Ribeirão Preto Faculty of Medicine,University of São Paulo, Brazil.

II MD, Resident, Division of Coloproctology,Department of Surgery and Anatomy, Ribeirão Preto Faculty of Medicine, University of São Paulo, Brazil.

III MD, Resident, Division of Coloproctology, Department of Surgery and Anatomy, Ribeirão Preto Faculty of Medicine, University of São Paulo, Brazil.

IV MD, Fellow PhD degree, Division of Coloproctology, Department of Surgery and Anatomy, Ribeirão Preto Faculty of Medicine, University of São Paulo, Brazil.

PhD, Professor, Division of Coloproctology, Department of Surgery and Anatomy, Ribeirão Preto Faculty of Medicine,

Un PhD, Professor, Division of Coloproctology, Department of Surgery and Anatomy, Ribeirão Preto Faculty of Medicine,
(a) University of São Paulo, Brazil.

\begin{abstract}
Purpose: Colonoscopy plays an essential role in the therapeutic and diagnostic approach in various colonic pathologies, the aim of the present study was to compare three solutions and their efficacy for the bowel preparation in adult patients submitted to elective colonoscopy. Methods: Sixty patients were randomly divided into three groups of 20 each. Each group was submitted to a bowel preparation with one of the following solutions: $10 \%$ manitol, sodium picosulphate or sodium phosphate. The parameters evaluated were: taste, tolerance, associated side effects and quality of cleansing. Postural blood pressure and pulse rate as well as serum sodium, potassium, calcium and phosphate were compared. Results: Sodium phosphate and 10\% manitol solutions provided superior results in terms of colon cleansing compared to sodium picosulphate solution. All serum electrolytes evaluated were significantly altered in the three groups, without important clinical signs. Discussion: High levels of serum phosphate were the most striking alteration in patients prepared with sodium phosphate solution, again with no clinical signs. Variations related to blood pressure and pulse rate suggested contraction of intravascular volume, with no clinical effects. Conclusion: Sodium phosphate and 10\% manitol solutions are equivalent in providing good quality colon cleansing, with no significant side effects that could compromise the procedure.
\end{abstract}

Key words: Bowel Preparation. Sodium Phosphate. Manitol. Sodium Picosulphate.

\section{RESUMO}

Introdução: A colonoscopia é exame fundamental na avaliação das doenças do cólon e na abordagem terapêutica de determinado grupo de patologias. O preparo intestinal é obrigatório para a realização das colonoscopias eletivas, e a qualidade encontra-se relacionada ao sucesso do procedimento. Comparou-se três soluções para limpeza anterógrada do cólon em pacientes adultos, submetidos à colonoscopia. Metodos: Sessenta pacientes foram distribuídos em três grupos de vinte. Cada grupo realizou o preparo do cólon com uma das três soluções estudadas: manitol a $10 \%$ (MN), picossulfato sódico (PS) e fosfato monobásico e dibásico de sódio (NaP). O sabor, a tolerância, os efeitos colaterais, os custos e a qualidade de limpeza do preparo foram avaliados. Frequência cardíaca e pressão arterial sistêmica foram analisados. Variações dos eletrólitos foram dosados antes e após o preparo. Resultados: Os resultados foram semelhantes em relação aos ef̧eitos colaterais. O sabor da solução de NaP não chegou a comprometer a sua aceitação. Discussão: Soluções de NaP e MN proporcionaram resultados superiores tanto em qualidade de limpeza colônica, como em relação aos custos, quando comparadas à solução de PS. Conclusão: Comparados os três, os eletrólitos avaliados apresentaram diferenças significativas, sendo a hiperfosfatemia dos pacientes com a solução de NaP, a mais importante.

Descritores: Preparo de Cólon. Fosfato de Sódio. Manitol. Picossulfato de Sódio.

1. Study performed in the Division of Coloproctology of the Department of Surgery and Anatomy of Ribeirão Preto Faculty of Medicine, University of São Paulo, Brazil. 


\section{Introduction}

In the last decade, colonoscopy has been used as the first-choice procedure, either for diagnosis or treatment of various colonic lesions, having substituted the barium enema. Nevertheless, to ensure success of the procedure, it is necessary an efficient bowel preparation: a high-quality colon-cleansing, associated with safe, efficient and of good tolerance solutions and minimal side effects would be ideal. ${ }^{1,2}$ Two methods for colon cleansing are available: the anterograde, which uses the natural bowel outflow, and the retrograde, by means of colonic lavage. In recent years, most authors have been using anterograde methods for bowel preparation due to its good quality cleansing and also to the patients' tolerance and acceptance. Various colon-cleansing solutions have been used in the last 30 years, being the saline ${ }^{3}$ manitol, ${ }^{4}$ polyethylene-glycol, ${ }^{5}$ sodium picosulphate ${ }^{6}$ and sodium phosphate ${ }^{7}$ the most widely used solutions. Nevertheless, there are few reports dealing with the clinical comparison between these solutions in the bowel preparation. In this way, the aim of the present study was to compare three widely used solutions (manitol $10 \%$, sodium phosphate and sodium picosulphate) and their efficacy for the colonic cleansing in adult patients submitted to elective colonoscopy. Comparisons were made in order to evaluate the cleansing quality, side effects with clinical significance, taste, tolerance and costs associated to each of the solutions. ${ }^{8}$

\section{Methods}

Sixty ambulatory patients that would be submitted to colonoscopy were randomly divided into three groups of 20 patients each. All patients were equally instructed about the appropriate bowel preparation regimens which constituted of a liquid diet associated with $10 \mathrm{mg}$ of sodium picossulphate on the day before the colonoscopy. On the day before this, patients were instructed to have a low fiber diet. Liquid intake was stimulated on these two days before the colonoscopy, being milk and dark colored juices forbidden. Written informed consent was obtained from all of the patients. Exclusion criteria were previous myocardial infarction, cardiac failure, renal failure, hepatic failure, signs of intestinal pseudo-obstruction, previous colectomy, cerebrovascular disease and serum electrolytes disturbance.

Patients prepared with manitol $10 \%(\mathrm{MN})$ had to take $1000 \mathrm{ml}$ of the solution in one hour, 4 hours before the colonoscopy. Those who received sodium phosphate solution $(\mathrm{NaP})$, ingested $130 \mathrm{ml}$ of a solution composed by $16 \mathrm{~g}$ of $\mathrm{NaPO}_{4} \cdot \mathrm{H}_{2} \mathrm{O}$ (monobasic) and $6 \mathrm{~g}$ of $\mathrm{Na}_{2} \mathrm{HPO}_{4} \cdot 7 \mathrm{H}_{2} \mathrm{O}$ (dibasic) in $100 \mathrm{ml}$, in 15 minutes, 3 hours before the colonoscopy. Those who received the sodium picossulphate solution (PS) were oriented to follow the product instructions, taking one bag at 8:00 A.M and a second one at 4:00 P.M., on the day before the colonoscopy.

Immediately before the colonoscopy, patients filled a questionnaire recording tolerance, side effects, clinical symptoms, taste and any other relevant aspect about the preparations. The colon-cleansing quality was evaluated by colon and rectal surgeons who were blinded to the bowel preparation regimen. The evaluation followed the criteria suggested by Vanner et $\mathrm{al}^{8}$ and graded as excellent (none or small amount of residual fluid), good (large amount of clear liquid easily aspirated), regular (liquid faeces, that could be easily aspirated) and poor (solid faeces, impossible to aspirate).

Serum electrolyte (sodium, potassium, calcium and phosphate), as also as hematocrit and hemoglobin, were measured 24 hours before the bowel preparation and immediately before the colonoscopy. Blood pressure and its postural variations, pulse rate and blood oxygen were systematically monitored during the procedure.

Pre-and post-colonoscopy data were compared intra-groups by the non parametric test of Wilcoxon. Data were compared between groups by Kruskal-Wallis analysis, followed by the Miller test. Side effects data were compared by the Qui-square goodness of fit test $\left(X_{2}\right)$. Differences were considered significant when $\mathrm{p}<0.05$.

\section{Results}

All patients were able to tolerate and complete the preparation regimen, despite that the PS was better tolerated than the $\mathrm{NaP}$ followed by the MN solutions, with a statistical significance between PS and MN. Taste was also better evaluated for PS, compared to $\mathrm{MN}$ and $\mathrm{NaP}$, being $\mathrm{NaP}$ significantly worse than the other two.

The colon-cleansing quality was excellent or good in $78 \%$ of the patients and poor in only $3 \%$. Patients prepared with $\mathrm{NaP}$ were graded excellent or good in $95 \%$ while patients prepared with MN or PS were graded excellent or good in $90 \%$ and $50 \%$ respectively, with significant differences between PS and the other two methods. There were no significant differences between groups on the side effects evaluation and $87 \%$ of the patients referred tolerable symptoms during the preparation.

Postural blood pressure variation was evaluated before and after the colonoscopy, and showed a strong, but not significant, tendency to smaller values of the systolic pressure in all groups studied. Higher, but not significant, pulse rate values were observed in all groups at the end of bowel preparation.

Groups MN and PS showed a significantly high hematocrit after the preparations, but the opposite was observed in the $\mathrm{NaP}$ group. Comparison between groups showed significant differences between $\mathrm{NaP}$ and the other two.

In relation to serum electrolytes, sodium was significantly decreased with the PS preparation and significantly increased with the $\mathrm{MN}$ and $\mathrm{NaP}$ preparations. Also, a significant difference was found between PS and the other two solutions. Potassium was significantly decreased after bowel preparation in the PS and $\mathrm{NaP}$ groups and significantly increased in the MN group. Differences between groups were significant only between $\mathrm{NaP}$ and MN. Serum phosphate was not different before and after bowel preparations and also between groups MN and PS. Nevertheless, the NaP group showed a significant raise in the serum phosphate after bowel preparation and also when compared to the other two groups. Serum calcium was 
significantly elevated after bowel preparation in the PS group but decreased on groups $\mathrm{NaP}$ and MN. Significant differences were observed between $\mathrm{NaP}$ and PS groups.

Costs were lower for the NaP solution, followed by the MN and PS solutions.

\section{Discussion}

Our data clearly showed a higher tolerance and better taste for the PS solution, compared to $\mathrm{MN}$ and $\mathrm{NaP}$. This is certainly a result of the combination between good taste and small volumes of the PS solution since such a combination was not encountered for the $\mathrm{NaP}$ (worse taste) or for the MN (large volume) solutions. Despite the taste and volume, all patients were able to complete the proposed treatments, as shown by other authors. ${ }^{7}$

Side effects associated to colon cleansing solutions have been disappearing since the decay of the saline solution for that purpose. With solutions for the anterograde colon cleansing, side effects are less intense and usually restricted to abdominal pain, nausea, vomiting and abdominal bloating. ${ }^{9,10}$ The present study showed that $28 \%$ of the patients did not refer any side effect and only $58 \%$ referred mild symptoms, totalizing $86 \%$ of patients with no symptoms with clinical relevance. In $1,5 \%$ of the patients, clinical alterations due to dehydration were present.

In terms of quality of the bowel preparation for colonoscopy, it is widely accepted that safety and success of the procedure is due to a high-quality cleansing, independently of the method. ${ }^{11,12}$ Our results showed $95 \%$ of cleansing with excellent or good quality for $\mathrm{NaP}$ group, $90 \%$ for the MN group and 50\% for the PS group, with significant difference between the PS and the other two groups. The main reason for this difference was the presence of faeces adhered to the right colon walls in patients with the PS preparation.

With advancing on the bowel preparation solutions, differences on quality of preparation among solutions are being less pronounced. In this way, data about tolerance and costs of a specific method are of importance and should be taken into account when indicating one of them. ${ }^{13-16}$ The present study provides an actual evaluation of costs associated with three methods, taking into account the commercial value of the products. A small difference was observed between the $\mathrm{MN}$ and $\mathrm{NaP}$ solutions, being the last one more affordable. PS solution cost was $50 \%$ and $36 \%$ higher than the $\mathrm{NaP}$ and $\mathrm{MN}$ solutions, respectively.

Most of recent studies have demonstrated some degree of dehydration, associated with different methods of anterograde bowel preparation. Our blood pressure, pulse rate and hematrocrit data suggested that there was a decrease in the intravascular volume of all patients. Nevertheless, these alterations were not related to significant clinical symptoms, indicating that the procedures for the bowel preparation used in the present study were safe.

In parallel with the search for colon cleansing methods with very high quality, the electrolytic alterations and their clinical implications have been subject of many investigations, in order to identify the ideal solution that would cause minimal serum electrolyte disturbance. ${ }^{7,17-19}$ Our results showed that patients prepared with $\mathrm{NaP}$ and $\mathrm{MN}$ presented high serum sodium after the bowel preparation, being this elevation more significant on the MN patients. PS patients had a decrease in serum sodium, and differences were observed between PS compared to the other two groups.

Significant lower serum potassium was observed on the NaP group. The increased serum potassium observed on the MN group was not previously reported ${ }^{19,20}$ and was not statically significant. On the comparison between groups, significant differences were present only between $\mathrm{NaP}$ and $\mathrm{MN}$ groups.

Some literature reports describe a rise on the serum phosphate in those patients prepared with the NaP solutions, including the description of one death due to this alteration. ${ }^{19}$ The high serum phosphate observed in $100 \%$ of the NaP group was the most important alteration in our electrolyte evaluation, also with high statistical significance. Patients prepared with $\mathrm{MN}$ also showed increased serum phosphate, but with no statistical significance, and no important alteration was found on group PS. Differences between NaP and the other two groups were statistically significant. No NaP patient showed clinical relevant signs and/or symptoms.

Serum calcium was smaller, but not significantly, after bowel preparation with $\mathrm{NaP}$ and $\mathrm{MN}$, as described in the literature ${ }^{20}$ but was significantly elevated on the PS group. Statistical differences were observed only between groups $\mathrm{NaP}$ and PS, without any observed side effect.

In conclusion, the present study demonstrated that $\mathrm{NaP}$ and $\mathrm{MN}$ solutions showed a higher quality in the colon cleansing, compared to the PS solution. Serum electrolyte was altered on the three groups but not associated to clinical symptoms or relevant side effects, thus not interfering with the methods safety.

\section{References}

1. Delegge M, Kaplan R. Efficacy of bowel preparation with the use of a prepackaged, low fibre diet with a low sodium, magnesium citrate cathartic vs. a clear liquid diet with a standard sodium phosphate cathartic. Aliment Pharmacol Ther. 2005;21:1491-5.

2. Froehlich F, Wietlisbach V, Gonvers JJ, Burnand B, Vader JP. Impact of colonic cleansing on quality and diagnostic yield of colonoscopy: the European panel of appropriateness of gastrointestinal endoscopy European multicenter study. Gastrointest Endosc. 2005;3:378-84

3. Hewitt J, Rigby J, Reeve J, Rigby J, Cox AG. Investigation in preparation for large bowel surgery. Lancet. 1973;2:337-40

4. Champault G, Patel JC. Apropos of the communication by L. F. Holiender: Our experience with wash out in colon surgery. Colon preparation; usefulness of digestive irrigation with oral absorption of 10 percent Mannitol. Chirurgie. 1977;103:998-9.

5. Davis GR, Santa Ana CA, Morawski SG, Fordtram JS. Development of a lavage solution associated with minimal water and electrolyte absorption or secretion. Gastroenterology. 1980;78:991-5.

6. De Lacey G, Benson M, Wilkins R, Spencer J, Cramer B. Routine colonic lavage is unnecessary for double- 
contrast barium enema in outpatients. Br Med J. 1982;1021-2.

7. Law WL, Choi HK, Chu KW, Ho JW, Wong L. Bowel preparation for colonoscopy: a randomized controlled trial comparing polyethylene glucol solution, one dose and two doses of oral sodium phosphate solution. Asian J Surg. 2004;27:120-4.

8. Vanner SJ, Macdonald MD, Paterson WG, Prentice RS, Da costa LR, Beck IT. A randomized prospectivo trial comparing oral sodium phosphate with standard polyethylene glycol-based lavage solution (Golytely) in the preparation of patients for colonoscopy. Am J Gastroenterol. 1990;85:422-7.

9. Curran MP, Plsker GL. Oral sodium phosphate solution: a review of its use as a colorectal cleanser. Durgs. 2004;64:1697-714.

10. Habr-Gama A, Hahas SC, Calache JE. Preparo intestinal para colonoscopia: solução de manitol vs solução de fosfato de sódio. Estudo prospectivo e randomizado. Rev Bras Coloproct. 1998;18:42-5.

11. Dean ACB, Newell JP. Colonoscopy in the differential diagnosis of carcinoma from diverticulitis ofthe sigmoid colono. Br J Surg. 1973;60:633-5.

12. Unal S, Dogan UB, Ozturk Z, Cindoruk M. A randomized prospective trial comparing 45 and $90-\mathrm{ml}$ oral sodium phosphate with X-prep in the preparation of patients for colonoscopy. Acta Gastroenterol Bei. 1998;61:2814.

13. Afridi SA, Barthel JS, King PD Pineda JJ, Marshall JB. Prospective, randomized trial comparing a new sodium phosphate-bisacodyl regimen with conventional PEGES lavage for outpatient colonoscopy preparation. Gastrointest Endosc. 1995;41:485-9.

14. Barclay RL. Safety, efficacy and patient tolerance of a three-dose regimen of orally administered aqueous sodium phosphate for colonic cleansing before colonoscopy. Gastrointest Endosc. 2004;60:527-33.

15. Girard CM, Rugh KS, Dipalma JA, Brady CE, Pierson WP. Comparison of Golytely lavage with standard dietlcathartic preparation for double-contrast barium enema. Am J Roentgenol. 1984;142:1147-9.

16. Wamer BA, Dipalma JA. Oral sodium phosphate catharsis: "first do not harm". Am J Gastroenterol. 1994;89:1118-9.

17. Dipalma JA, Brady CE, Stewart DL, Karlin DA, Mc Kinney MK, Clement DJ, Coleman TW, Pierson WP. Comparison of colon cleansing methods in preparation for colonoscopy. Gastroenterology. 1984;86:856-60.

18. Frizelle FA, Colls BM. Hyponatremia and seizures after bowel preparation: report of three cases. Dis Colou Rectum. 2005;48:393-6.

19. Huppertz-Hauss G, Bretthauer M, Sauar J, Paulsen J, Kjellevold $\varnothing$, Majak B, Hoff G. Polyethylene glucol versus sodium phosphate in bowel cleansing for colonoscopy: a randomized trial. Endoscopy. 2005;37:537-41.

20. Ainley EJ, Winwood PH, Begley JP. Measurement of serum electrolytes and phosphate after sodium phosphate colonoscopy bowel preparation: an evaluation. Dig Dis Sci. 2005;50:1319-23.

\section{Correspondence:}

Omar Féres, $\mathrm{PhD}$

Department of Surgery and Anatomy

Ribeirão Preto Faculty of Medicine, University of São Paulo

Av. Bandeirantes 3900,

14048-900 Ribeirão Preto, SP, Brazil

Phone: +55 163602-2509

feresomar@netsite.com.br

\section{How to cite this article:}

Miki Jr P, Lemos CRR, Popoutchi P, Garcia RLS, Rocha JJR, Féres O : Estudo comparativo entre as soluções de manitol, picossulfato de sódio e fosfato monobásico e dibásico de sódio no preparo de cólon para colonoscopia. Acta Cir Bras [serial on the Internet], 2008; 23 Suppl 1. Available from URL: http://www.scielo.br/acb.

\section{Comments:}

Clinical studies to best define colon preparation conditions for colonoscopy comprise subjective evaluations by patient and doctor besides clinical and laboratorial observations during the procedure. Criteria like time spent by the patient, tolerance to the ingested solution and symptoms, if any, during this period are important variables and should be documented. Evaluation by the doctor performing the exam will be another important variable characterizing the preparation. The study entitled" Comparative study of solutions of mannitol, sodium picosulfate and monobasic and dibasic sodium phosphates in colon preparation for colonoscopy" was performed with an adequate number of patients and included important variables contributing to conclusions and decisions about the best colon preparation for endoscopic exams. Preparations with sodium picosulfate were started the day before the exam and although this procedure could be the one least tolerated by the patient, this was not recorded. Results in relation to preparation quality were similar for all groups, the only distinctive alterations being related to clinical-laboratorial observations. Comparative cost of the solutions was also discussed. The study presents consistent results to support options in colon preparation for endoscopy

\section{Carlos Augusto Teixeira da Cruz}

MD, Associate Professor, Clinical Surgery, Faculty of Medicine, University of Brasilia 